\title{
THE TRANSFORMED BEHOLDER: OBJECTIVE BEAUTY AS THE IMPETUS FOR SANCTIFICATION IN THE THEOLOGY OFHANS URS VON BALTHASAR
}

\author{
SAM WELBAUM* \\ California Baptist University
}

\begin{abstract}
Here in the early 21 st century, beauty is not what it once was. The Enlightenment has left beauty a subjective and inconsequential shade, barely resembling its former existence as a transcendental on par with goodness and truth. Can beauty be restored to what it once was? And if it can, should it? This article argues that 20th century theologian Hans Urs von Balthasar not only answers these two questions with a resounding "Yes!" but also gives the church the tools needed to restore beauty to a place of honor in Christian theology. For von Balthasar, beauty and glory are one in the same. Further, beauty/glory and love are irrevocably connected. When we restore beauty to its proper place, we experience God's love in a proper way, which in turn leads to sanctification.
\end{abstract}

KEY WORDS: Beauty, Sanctification, Glory, Sublime, Love

Dr. Crispin Sartwell tells a story of traveling abroad and touring a Venetian cathedral. Sartwell is an atheist, but he admits that inside the cathedral, the beauty was so overwhelming that it was as though he felt a presence inside him. Something about the cathedral stirred in him a feeling that he recollects as a yearning for God. ${ }^{1}$ Though Sartwell remains an atheist, he has stumbled upon a connection embraced by Christians across the millennia: There is a noted interrelation between God and beauty.

Sadly, this connection has weakened in certain traditions in the last few centuries. Weakened, not in the sense that God has become less beautiful;

* SAM WELBAUM holds Masters degrees from Biola University and Golden Gate Baptist Theological Seminary. He is presently working on a PhD in Philosophy of Religion and Theology and serves as adjunct faculty for the School of Christian Ministries at California Baptist University.

1 Crispin Sartwell, Six Names of Beauty (New York, NY: Routledge, 2006), 58.

(C) EMANUEL UNIVERSITY of ORADEA

PERICHORESIS $10.2(2012)$ 
but rather that God's beauty has been overlooked or given merely nominal attention. Hans Urs von Balthasar has critiqued Protestantism as merely mining over Scripture to obtain data and facts, but losing touch with beauty in the process. ${ }^{2}$ Von Balthasar notes that truth without beauty loses its cogency and goodness without beauty loses its attractiveness. ${ }^{3}$ That loss of attraction goes a long way in explaining the present state of our churches. The exodus that happens once teens leave High School and the shallowness or dearth of sanctification both can be traced to this concern that von Balthasar illumines in his work. For von Balthasar, beauty is an objective reality, and the accurate perception of that objective beauty, which is grounded in God, leads to sanctification and the transformation of the beholder. In order to fully understand the connection between beauty and sanctification in von Balthasar's thought we will need to first address the question "What is beauty?" including issues related to sublimity, objectivity and love; and only then proceed to the interplay between beauty and sanctification.

\section{What is Beauty?}

Defining beauty is by no means an easy task. In our current context, words such as "pretty" or "cute" seem to be used as synonyms for beauty, yet they seem to cheapen the concept. They are a part of the abuse of beauty that von Balthasar decries in the first volume of his The Glory of the Lord. ${ }^{4}$ Beauty has fallen from a privileged place not just in the church, but in society as well. Sartwell has suggested that whatever we desire we learn to find beautiful. ${ }^{5}$ In this system, beauty is not something that causes desire; rather beauty is an after effect of desire. If a person desires something and only then begins to see it as beautiful, there can be no connection between beauty and sanctification, and truthfully, a connection between God and beauty would be difficult to note. If God is only beautiful because I desire Him, then does the statement "God is beautiful" mean anything beyond "I desire God"? It in fact cannot. view 101.1 (2008): 45.

3 Hans Urs von Balthasar, The Glory of the Lord. A Theological Aesthetics; I. Seeing the Form, ed. by Joseph Fessio and John Riches, trans. by Erasmo Leiva-Merikakis (San Francisco, CA: Ignatius, 1982), 19.

$4 \quad$ Ibid.

$5 \quad$ Sartwell, Six Names of Beauty, 6.

PERICHORESIS 10.2 (2012) 
Von Balthasar would not disagree with Sartwell's conception in total; however, he would note that Sartwell ended his discussion too soon and perhaps used incorrect terms. For von Balthasar, it is true that the things we love will appear to us as beautiful. It is important that in von Balthasar's thought, desire and love are connected in a way that is completely foreign to Sartwell. Further, he continues, we will love that which we perceive as beautiful. ${ }^{6}$ Von Balthasar presents a circle where Sartwell presents a line. Not only does something appear beautiful because a person loves it, but a person loves it because it is beautiful. This relation provides perpetual motion and increase in both love and beauty on the part of the observer.

Still, we have yet to reach an actual definition of beauty. David Bently Hart has suggested that the Christian concept of beauty is connected to the riches of being itself. ${ }^{7}$ Beauty is not merely in the eye of the beholder, nor is it related to the superficial world, but beauty is an issue of metaphysics, an issue of form. Von Balthasar asserts that anyone who is unable to see the form of an object will be unable to read or understand the content of that object. ${ }^{8}$ In other words, beauty is concerned with the very essence of an object, and when someone is unable to perceive the essence of an object, that person will be unable to understand the beauty, or any of the content, of that object. The aesthetic that von Balthasar presents is one that is centered on the perception, by the eyes of faith, of God's self-interpreting glory. ${ }^{9}$ The absolute form, the absolute essence, of beauty is God's self-revelation to the world. It is for this reason that von Balthasar's work on beauty is called The Glory of the Lord; in his thought, beauty and glory are synonyms.

If beauty means glory, and in particular the freely given glory of the Lord, then why does there seem to be such dissonance between God's glory and what is labeled as beautiful in the contemporary church and in our current society? Von Balthasar is presenting an understanding of beauty which is transcendent; one in which the truly beautiful takes possession of the observer. This is a conception of aesthetics in which beauty presents a challenge to the average and mundane. ${ }^{10}$ However, this transcendental concept

6 Hans Urs von Balthasar, Love Alone Is Credible, trans. by D. C. Schindler (San Francisco, CA: Ignatius, 2004), 54.

7 David Bentley Hart, The Beauty of Infinite. The Aesthetics of Christian Truth (Grand Rapids, MI: Eerdmans, 2003), 18.

von Balthasar, The Glory of the Lord I, 151.

Ibid., 59.

10 Hans Urs von Balthasar, Theo-drama. Theological Dramatics; II. Dramatis Personae. Man in God, trans. by Graham Harrison (San Francisco, CA: Ignatius, 1976), 24.

PERICHORESIS 10.2 (2012) 
of beauty is no longer the norm. John O'Donahue observes that in our present society, having lost sight of the transcendent, we often confuse glamour with beauty. ${ }^{11}$ Humankind is so taken in by the cheap physical features of shallow distraction that we've lost the understanding of essence as it pertains to beauty. Elaine Scarry has properly understood the issue when she notes that beauty is damaged with the removal of either the sacred or the metaphysical realms. Without the realm of being behind aesthetics, objects can no longer bear their own beauty, and the concept of beauty crumbles just as O'Donahue warned it would. ${ }^{12}$

What then is beauty? Von Balthasar claimed that "Glory cannot be defined". ${ }^{13}$ Glory (and therefore beauty) is God's self-disclosing revelation which, when presented to mankind is both enrapturing and crushing. Von Balthasar sees in God's beauty both an element of fear and of unattainable majesty. Unlike the glamour that is so often called beauty, God's beauty demands adoration. ${ }^{14}$ Why then the differentiation between von Balthasar's concept of beauty and the contemporary concept of beauty? The removal of the sublime from the beautiful.

\section{Beauty and the Sublime}

In contrast to von Balthasar's position, Crispin Sartwell is confused by the idea that people conceive of beauty as eternal. Beauty, according to Sartwell, is finitude. ${ }^{15}$ It must exist within temporal boundaries. If beauty were to exist beyond temporal boundaries, it would then remind us of our mortality and instill within us a sense a dread; a sense of dread that is foreign to a 21 st century understanding of beauty. Sartwell holds that the experience of such dread is almost an event of worship; however, the cause of such an experience is not beauty, but sublimity. ${ }^{16}$ The sublime is a deep and profound category that stirs the human mind and draws awe and wonder out of the one who beholds a sight infused with it. Mount Everest, Niagara 2004), 5.

12 Elaine Scarry, On Beauty and Being Just (Princeton, NJ: Princeton University Press, 1999), 46.

13 Hans Urs von Balthasar, The Glory of the Lord. A Theological Aesthetics, IV. The Realm of Metaphysics in Antiquity, ed. by John Riches, trans. by Oliver Davies et al. (San Francisco, CA: Ignatius, 1989), 11. von Balthasar, The Glory of the Lord I, 321 . Sartwell, Six Names of Beauty, 152. Ibid., 18. 
Falls, the Aurora Borealis, they all stir something deep within the beholder, changing him or her profoundly in ways that Sartwell, and other contemporary thinkers believe beauty cannot; yet these are the same changes that von Balthasar is rather confident that beauty, the revealed form of God's glory, can and does accomplish.

The key difference between von Balthasar and Sartwell (and by extension much of contemporary aesthetics) is found in the work of the 18th century thinkers Edmund Burke and Immanuel Kant. These two thinkers drove a wedge between the sublime and the beautiful, leaving the sublime ominous and the beautiful weakened. Scarry characterizes the two categories by means of contrast. In a post-Kant/Burke understanding, night is sublime, while day is beautiful. The sacred oak is sublime, while a flower is beautiful. The sublime can move the beholder, while the beautiful charms her. This distinction left the sublime as almost a profound source of dread, while the beautiful has become a passing fancy. Scarry asserts that this distinction has cheapened beauty, but it seems that it has cheapened the sublime as well. ${ }^{17}$ Without the metaphysical grounding that the sublime offers, beauty can be diminished to mere "prettiness". Roger Scruton points out that in our present world, art has replaced nature as the main area of conversation regarding aesthetics and due impart to the work of the media, effect in art has replaced meaning in aesthetics. ${ }^{18}$ If art has replaced nature, and done so primarily by means of effect as opposed to meaning, it should not be surprising that beauty has fallen into disrepair in the contemporary church.

Clayton Crokett however, believes that von Balthasar holds the key to restoring beauty in the church (and in society) by acting as a corrective to Kant and Burke. In Crokett's estimation, von Balthasar has put the sublime in the service of the beautiful. ${ }^{19}$ No longer are the two distant and completely separate ideas, one fearful and one saccharine; rather they are once again wed into one solid category which has the transcendental ability to be both distant and imminent. Commenting on the situation himself, von Balthasar notes that prior to Kant, beauty was part of metaphysics and traces of beauty were part of the depths of being. ${ }^{20}$ Whereas Sartwell is operating in a Kantian understanding of beauty, von Balthasar has wisely returned to a pre-Kantian understanding, in which beauty is grounded in ontology, in be- 
ing itself. Since God is the ground and source of all being, what von Balthasar has done is returned to an understanding in which God is the central fount and origin of beauty, and by restoring the connection between the beautiful and the sublime, he has wed again the concepts of God's transcenddence with His immanence. In this manner, von Balthasar has solidified a Christian understanding of beauty, based on the being of God, with the power to both draw and transform the beholder. However, before pursuing this line of thought, we must address the issue of beauty and objectivity.

\section{Beauty and Objectivity}

It is paramount for von Balthasar that we develop a theological aesthetic as opposed to an aesthetic theology. The difference that he sees in these two concepts is that the former is grounded in God as the source of beauty, as opposed to the latter, which sees beauty as a label that the observer is able to bestow. In an aesthetic theology, the beholder calls beautiful only that which the beholder finds pleasing, with no concern for the wider question of what actually is beautiful. In so doing, the beholder cheapens the concept of beauty by selling out its substance. ${ }^{21}$ As we have seen, however, in a world that has dismissed metaphysics, and has separated the sublime from the beautiful, von Balthasar's objective theological aesthetic is a foreign concept, while the subjective aesthetic theology seems to be the only logical recourse. Is there then any reason to favor von Balthasar's objective understanding of beauty?

Contemporary wisdom indicates that beauty is in the eye of the beholdder. Something is beautiful merely because I find it to be so. Sartwell suggests that anything we long for becomes beautiful in the given situation in which we long for it. ${ }^{22}$ For example, the ocean is beautiful in this conception if and only if a person is in such a place, mood or situation that she desires the ocean. If she does not long for the ocean, then the ocean lacks beauty. O'Donahue takes a different approach to the issue of subjective beauty, suggesting instead that beauty is in the eye of the beholder if and only if we mean by the statement that beauty is contingent on a new and transformed way of seeing. If the eyes of the observer are trained to see beautifully, and to perceive beauty as opposed to decree beauty, then in his system, beauty

21 von Balthasar, The Glory of the Lord I, 38.

22 Sartwell, Six Names of Beauty, 3.

PERICHORESIS 10.2 (2012) 
can reside in the eye of the beholder, because it is a proper reflection of what exists in the essence of the thing observed. ${ }^{23}$

Perhaps the best case in the modern secular world for the objective nature of beauty is found in the work of Roger Scruton. Scruton asserts that when an individual makes the claim that something is beautiful, he makes a claim about the object itself, not about his own feelings. If he claims that a vase is beautiful, he is not saying, "That vase causes me to feel beautiful feelings" but rather "The vase I am beholding is beautiful, and anyone else whose senses are working properly will see it as such". ${ }^{24}$ For Scruton, apprehension of the beautiful is contingent on properly working faculties, but to presume that beauty's objective nature must be denied due to the existence of improperly working faculties is similar to asserting that the existence of a blind person removes all colors from existence.

What about the way that beauty is perceived? Since perception of the beautiful is contingent on subjective experience, is it not possible to maintain that even if beauty is objective, one could never know it? Scruton dismisses this idea. He agrees that aesthetic judgment is indeed rooted in subjective experience, but a subjective experience of an objective reality does not make the reality any less objective. ${ }^{25}$ I perceive the greenness of the grass in a subjective manner, but that does not mean that the grass is not green. In fact, what it does mean is that either the grass is actually green, or my faculties are damaged. If my faculties are damaged, I will never be able to perceive reality until they are restored to proper working order.

Are we then to presume that any differentiation between what people enjoy is truthfully nothing more than a privation in the faculties? Not entirely. It must be understood that taste is also involved in one's ability to perceive beauty. If a woman lacks a taste for sour cream or basketball, she will not be able to perceive what one who has a taste for them would be able to. Again, here it seems that beauty is in danger of becoming purely subjective. If tastes differ, then the term beautiful seems to mean nothing more than, "I have a positive taste for X". However, this assertion presumes that all tastes are equal. If a man has a taste for comic books but can find no beauty in Shakespeare, the privation is not in Shakespeare, but in the man. ${ }^{26}$ His

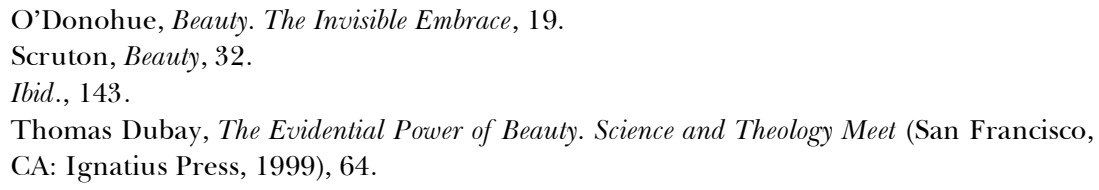


tastes are too weak. He is like the five year old who attempts to eat yellow curry before his tastes are ready for it. Not all tastes are equal, some must be learned, and some must be discouraged.

In a democratic society, Scruton observes, it is offensive to tell a person that her taste is flawed. This social pariah is grounded in the fact that our tastes are tightly wrapped into our moral identity and tied to our self-image. ${ }^{27}$ This connection explains why a morally depraved person might presume to find beauty in the shallows of a superficial life, when in fact; she has yet to even develop a taste for beauty. It is from this perspective that Hart critiques Nietzsche's disdain of Christianity as nothing more than Nietzsche having bad taste. ${ }^{28}$

Is it possible for someone such as Nietzsche to have his tastes changed? Scruton believes so and illustrates the point by means of analogy. Imagine that a woman does not have a taste for Brahms and therefore has dismissed his music. Her boyfriend implores her to give Brahms another chance and she does. Over time, she begins to gain a taste for Brahms' music, in part due to the beauty of the music, but also in part due to her relationship with her boyfriend.$^{29}$ A person's taste can change due to prolonged exposure, but also due to the beauty they see from, or the love they have for, the person exposing them to the object; most commonly it's a combination of the two. This change in a person's taste is what von Balthasar called attunement. ${ }^{30}$

As we have seen, it is possible to make a compelling case for the objective nature of beauty, without appealing to the divine. However, such beauty, while objective, still lacks the metaphysical grounding found in von Balthasar's system. Scruton has laid a solid foundation in this area, one on which von Balthasar's system is able to capitalize nicely. For von Balthasar, the perception of beauty comes via subjective experience. This understanding of perception applies not just to our physical eyes but to the eyes of faith (mankind's inherent ability to perceive God) as well. Yet, the beauty that the eyes of faith perceive is God's objective self-interpretation of His own glory. ${ }^{31}$ In their subjective perception, the eyes of faith see objective beauty. If the eyes of faith cannot see the Christ form, we can only conclude one of the

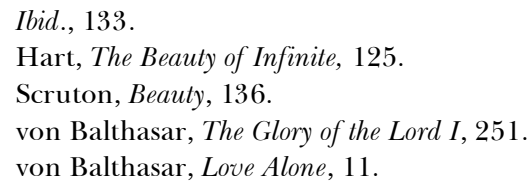

PERICHORESIS 10.2 (2012) 
following: there is no Christ form, the Christ form is purely subjective or there is a privation on the part of the beholder. Since the first of these options is clearly in error given that there is a ground for being, and the second has been dismissed by the work of Scruton, the final option is the one that must be accepted. A man's inability to perceive Christ tells us far more about the man's sin, than it does about Christ's beauty. ${ }^{32}$

Thomas Dubay affirms von Balthasar's position by pointing out that something can only be blind if there is something to perceive. If someone is blind to beauty that merely affirms Paul's assertions in Romans 1 that mankind suppresses truth and shuns that which it was created for, preferring to live in darkness. ${ }^{33}$ The lost, by definition, must perpetually shun the truth and beauty of God because the light of faith (the truth, goodness and beauty) of God's self-revelation perpetually shines forth to mankind, giving objective evidence of God's grandeur. ${ }^{34}$ Objective beauty is infused in the world and perpetually pours forth from the God who grounds the being of all things.

In light of the perpetual shining forth of beauty, it appears that von Balthasar leaves us with three possible responses: First, as we have already discussed, a person may be blind to the existence of beauty. Second, a person can attempt to destroy beauty. Scruton holds that people attempt to destroy beauty in various ways given that they are well aware that the existence of beauty calls them to renounce his or her own narcissism. ${ }^{35}$ What Scruton has noticed from the secular world applies all he more to the spiritual. It seems that some people may be aware that God exists and see His beauty in a faint and distant glow, but their hearts are so hard and full of sin that they desire more the destruction of anything that might cause them to relinquish the central position on the stage that is their life. These men and women lack a taste for God. As we shall see, the person of which this is true does not fully perceive the beauty of God, but is aware that such beauty exists and is full of hate toward it.

The third and final response is submission, or being overtaken by beauty. When a person has been attuned toward God, they are able to see His beauty pouring forth in both the material and physical world. Scarry notes that people who have erred in matters of beauty can often remember the

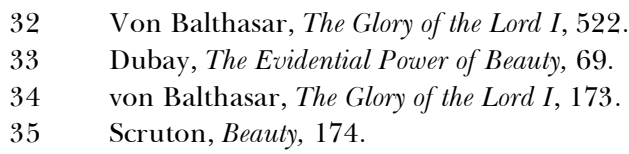


moment they realized they were wrong and that the object they were beholding was in fact beautiful. She compares the feeling to being slapped or having one's heart pierced.$^{36}$ The person who perceives this beauty is drawn into it and transformed by it. For von Balthasar, the perception of beauty leads to a change in the beholder.

\section{Beauty and Love}

Before addressing this change directly, one final matter pertaining to the nature of beauty must be addressed. For von Balthasar, beauty is grounded in the being of God. God's beauty is a reflection, or revelation, of who He is. Since von Balthasar takes Scripture seriously, and John tells us in his first epistle that "God is Love", it then follows that the being of God is infused with love. ${ }^{37}$ The connection that is drawn between these two lines of thought is clear: Beauty and love are irrevocably united. The point of von Balthasar's theological aesthetics is not merely to show that God is beautiful, but also to reveal that God is loving. Indeed, beauty is attractive because at its core is love.

Why is love attractive to mankind? What about love ties it with beauty in such a way that it has a gravitational pull and draws the beholder in? Dubay suggests that it might not be anything in love itself that draws mankind in; rather we were simply made to love and to receive love, so that when we experience love, it calls us back to the way things ought to be. It is his contention that those who live apart from God may use various means of distraction to ignore their inner longings, yet if they were to stop and meditate on the matter for any length of time, they would see that they deeply feel the need to love in an unbridled fashion. ${ }^{38}$ Dubay and von Balthasar agree on this point. In both of their conceptions, the human is a being designed particularly to long for love and yet lives isolated from this purpose. Why is mankind attracted to love? It seems that we can compare it to the feeling of returning to an activity that you once enjoyed and then drifted from. The first time a former athlete jogs after a surgery, or the feeling of going home after a long semester away; embracing God's love and returning God's love is beautiful and attractive because it is akin to going home.

\footnotetext{
36 Scarry, On Beauty, 12.

37 Francesca Murphey, ed., "Hans Urs von Balthasar: A Gateway to Love”, in Theological Aesthetics After von Balthasar, ed. by Oleg Bychkov and James Fodor (Hampshire: Ashgate, 2008), 6 . 
It feels this way because God implanted in our very being the light of faith and the desire for love. ${ }^{39}$ Humanity was made for love and by extension for beauty. One merely has to look around and see the destructive effects to the human condition when love is withheld. Love is the salve for anger, hate, greed, lust, depression, etc., and imagine all the more how God's love and beauty can be a salve to those same ills and a far grander scale. The current state of our world is the logical conclusion of a world apart from true love. Perhaps the world would suggest that it has true love. Von Balthasar disagrees, however. No matter how deep an emotion a person can muster toward another, or toward an object, it pales when confronted with the Almighty whose very being is love. This is not to say that God's being is emotion; but rather that love is much more than merely an emotion and when a sinner is confronted with this divine love, the sinner becomes painfully aware that he does not possess true love. ${ }^{40}$ The most beautiful expression of love for von Balthasar, is in the incarnate life, death and resurrection of Jesus the Word.

It is for this reason that von Balthasar can claim that the one who sneers at beauty can no longer pray and will eventually lose her ability to love. ${ }^{41}$ To shun beauty is not merely to reject an object's "prettiness", rather it is an assault on the being of God. Beauty calls mankind toward God, calling men and women to contemplate the One who creates, sustains and loves; to shun beauty is to shun such a call from God. In its greatest terms, to shun beauty is to shun the crucified Christ and to reject the love displayed on the cross. If a person is unable or unwilling to embrace God as such, then von Balthasar is clearly accurate in asserting that he will no longer be able to pray; and through perpetual rejection of the love of God and others (for love and beauty are completely intertwined) he will eventually become too jaded to love as well.

In order to reject love to this degree, a person must reject reality itself. God's being is love, and beauty is the conduit of love that irradiates all of creation. In volume 3 of The Glory of the Lord, von Balthasar discusses the thought of St. John of the Cross, who presents this idea in very striking terms. For St. John of the Cross, God perpetually shines forth His light and love into the world, illuminating the world by means of His grace. Once a person converts to Christianity and gives assent to the love that is pouring

von Balthasar, The Glory of the Lord I, 218.

von Balthasar, Love Alone, 61.

von Balthasar, The Glory of the Lord I, 18.

PERICHORESIS 10.2 (2012) 
forth from the Father, the convert becomes transparent and God's love no long reflects off him, but rather shines through him. Because the light of love is no longer being reflected, the convert then enters what is called a Dark Night of the Soul, in which he reflects God's light and love while seeing nothing but darkness. For St. John of the Cross, and concordantly for von Balthasar, the world gains its beauty from the divine love. ${ }^{42}$ To reject the divine love which cries out through beauty all around us is, as said before, to utterly reject reality.

It does seem to bear some mention that the rise of atheism started as mankind began to master nature. As humanity moved into cities, away from the beauty of nature, and began to study and manipulate the natural world, it seems as though the mystery of divine beauty began to fade. Once Kant and Burke had removed the sublime from the beautiful and metaphysics began to falter, atheism began to gain traction. Indeed, it could be no other way, because to reject metaphysics is to reject being, and to reject being is to reject the eternally revealed love of God. In truth, love and beauty become the greatest justification for belief in God, and the hardest things to explain without belief in God.

The convincing power of love is such because mankind was created for love, yet in his current state does not know love. Von Balthasar stresses that in his fallen state, man cannot know the true object of his desire unless God reveals it to him..$^{43}$ It is for this reason that we have dwelt on the issue of love and beauty: man is attracted to love and beauty yet in his ignorance hates it until God attunes his heart and mind to see it for what it really is. Once a person sees into the depths of beauty, and the very being of love, she finds her meaning for existence and echos back praises to the One who has healed her broken state. In Balthasar there seems to be two manners by which he believes this process that we may call "Conversion by Beauty" occurs: What I have called "The Way of Fire" and "The Way of Awe".

Von Balthasar is fond of fire imagery. The analogy of fire is prominent in volumes 6 and 7 of The Glory of Lord for both its brilliance and its purifying qualities. There is something about fire that catches our eye, and Louth, John Saward, Martin Simon and Rowan Williams (San Francisco: Ignatius, 1986), 149.

43 Hans Urs von Balthasar, Engagement with God, trans. by R. John Halliburton (San Francisco, CA: Ignatius, 1975), 71.

PERICHORESIS 10.2 (2012) 
though it is dangerous we are drawn to it. Yet, the danger is real. Anything that is perishable which comes in contact with the fire will be burnt and destroyed. In this destruction there may be pain, but the end result is purity for the one who endures the flames. Von Balthasar appeals to Isaiah's vision as an example of the flames of God's beauty burning away impurity. ${ }^{44}$ In his vision, Isaiah sees the glory of the Lord revealed, and realizes that he is himself unclean and unworthy. As Isaiah sees the revelation of divine beauty, he discards his narcissism and instead acknowledges his evil. A flaming coal is then used to symbolize the purifying effect of God's love. This picture of God's love and beauty as a fire grows in the New Testament, where von Balthasar emphasizes that this beauty will destroy all that is not love. ${ }^{45}$

Of the two modes that the Conversion by Beauty may take, von Balthasar's preferred is The Way of Awe. When one stands in front of a mountain range, she may feel overwhelmed, but it is not as though the mountains are usurping her freedom or faculties; rather they are inviting her to move beyond herself and to explore the range as best she can. This feeling of awe is miniscule compared to the feeling of awe that is experienced when one apprehends the beauty of God. Yet, von Balthasar holds firmly that God does not overwhelm a person. This does not mean that he does not find God overwhelming; rather it means that God does not move people by force. Previous statements that he has made about God's beauty being crushing and having a gravitational pull indicate that God's beauty overwhelms the beholder; however, it does not usurp the beholder. God's love and beauty overwhelm the beholder, but He does not conscript her will; rather He reveals Himself, and then leads the beholder, who chooses to seek His beauty. ${ }^{46}$

We have treated the issue of love and beauty at length and in such a manner that the terms seem interchangeable. We have done this, because for von Balthasar, the two concepts cannot be removed from one another. Beauty is what attracts us to God, and love is what attracts us to God. What, then, is the final estimation is this sublime objective and loving beauty? Though von Balthasar still maintains that glory cannot have a proper defiOld Covenant, trans. by Brian McNeil and Erasmo Leiva-Merikakis (San Francisco, CA: Ignatius, 1991), 247. 
nition, he agrees with Barth that God's glory is His self-revelation, His making Himself known to man. God has no need to do this, yet He does. The means of this revelation is love. ${ }^{47}$ Love in His sustaining power, love in His grandeur, love in His word and love seen most clearly in the crucifixion of His Son. Since beauty and glory are synonyms (remembering that God's glory cannot have a full and proper definition) and since God's beauty is presented solely through His love, we can conclude that to our initial question "What is beauty?" von Balthasar would simply answer, "Divine love".

\section{Beauty and Sanctification}

Elaine Scarry notes that beauty brings copies of itself into existence. The flower, the mountain or the sunset that is beautiful will move the artist to paint, the poet to write or the musician to play in such a way that the beauty of the object is reflected in the response. ${ }^{48}$ This replicating quality of beauty is what we mean when we assert that beauty is the impetus for sanctification. Von Balthasar does not see beauty as something that can be merely mentally acknowledged; rather it demands the response of the whole person. When enraptured in beauty, man becomes a "sounding box" or a mirror reflecting the divine love. ${ }^{49}$

Whenever we behold an object, von Balthasar suggests that we have only three possible responses: dominance, opposition or surrender. ${ }^{50}$ We are either repulsed by the object or we are drawn to it, and if drawn to the object, then we either desire to conquer it for ourselves, or to submit to its beauty and allow it to control us. It seems as though this delineation of categories is truncated as it applies to the material world, yet accurate as it applies to the spiritual. When the human is confronted with God's revelation, she will either desire to oppose God, attempt to control God or humbly bow before Him. The first two are indicative of poor taste and human narcissism respectively (and perhaps interchangeably) while the latter is indicative of a heart that has been attuned to the rhythms of God.

The attuned heart perceives God's beauty and embraces it. God's beauty does not satiate the need for beauty, but simultaneously satisfies and sparks a greater desire. As the heart perceives God's beauty at deeper and deeper 
levels, the heart transforms and images this beauty at deeper levels and is filled with a desire to extol and praise the God whose beauty is being perceived. ${ }^{51}$ By means of analogy, imagine an American tourist who is unfamiliar with Scotland. He travels there on vacation and is struck by the beauty of the moors and coastline. He faintly hears bagpipes being played and gets immediately attached to the sound. The love of the landscape and the music moves him to buy a kilt as a souvenir, and while making his purchase, he starts a conversation with the shop owner, which leads to a love of the Celtic speaking cadence. This newfound love leads him to spend hours in pubs learning about the culture of this land that he hardly knew anything about a week prior. Eventually, he realizes that he will never be happy again back in the States. Something has changed within him, and he is now a Scotsman in every way but genetics. His heart was changed by the beauty of Scotland and in turn he adopted that beauty as his own and reflected it in his choices. This is the same manner in which a believer is drawn deeper and deeper into God's beauty and is changed to resemble Him and display His beauty all the more. God's love elevates man from where he is, draws him in and then cultivates intimacy that leads to the believer's sanctification. ${ }^{52}$

The idea that God's beauty transforms the beholder is implicit in von Balthasar's aesthetics, however, by design, it becomes explicit in the dramatics. ${ }^{53}$ The aesthetics painted a picture of beauty possessing and changing the individual, but it's in the dramatic exchange between God and humankind that we see the display of that transformation. God does not reveal Himself for revelation's sake; rather He reveals Himself for the expressed purpose of commission. God reveals His love to mankind, not so they will know that He loves them, but so that they will no longer be the same as they once were.$^{54}$ The goal of God's revealed glory is to cause the beholder to grow in the Christian experience, which von Balthasar depicts as having one's life grow into the life of Christ. ${ }^{55}$ The deeper a person is drawn into the beauty of the Lord, the more accurately his actions will resemble the actions of his Lord. A proper appreciation for God's aesthetics will lead to a proper reflection of God's ethics. 
Our modern world seems to have lost the connection between beauty and action. As noted previously, modern art and the media seem to be more concerned about effect than they are about affect. Beauty is determined today by how an object makes an individual feel, rather than on its own merits. Or, beauty is determined by critics whose job is to seek out imperfection. In both cases, love is lost. In a very real way, and with vey real consequences, the Western world has been trained to be skeptical of beauty and therefore has damaged its ability to love. Unbridled skepticism and cynicism make it impossible for beauty to actually affect the human soul in anyway. The heart is too jaded and will immediately question and undermine any transformation that might attempt to occur as a response to beauty and therefore mitigates any change in action that might result from an altercation on the metaphysical plan. For this reason, cynicism and skepticism are enemies of beauty, whereas a childlike faith is an ally. Von Balthasar notes that the more childlike a person's faith, the more open she is to God and therefore the more mature she will be in her Christian growth and the more inclined she will be to helping others. ${ }^{56}$

Sanctification means becoming more holy, which entails developing a concern for others, in the same way that God has a concern for others. Beauty is at the essence of this facet of sanctification. When people see a sunset that is truly breathtaking, they will call it to the attention of those around them, or take a picture and send it to those they care about. Humans not only desire beauty, but we desire to share beauty with others as well. The more deeply we experience beauty, the more we desire to share that beauty with others, either in conversation or experientially. In speaking of the divine beauty, God's beauty not only gives us a desire to share His love, but it transforms us and makes us capable of true love. ${ }^{57}$ Here von Balthasar is not speaking of "true love" in the popular romantic sense, but in the true Christian sense, in which the lover cares deeply for the wellbeing of the loved. This is the same type of love that is grounded in the being of God and which He displays in His revealed glory.

As the beholder contemplates Christ, he begins to image Christ more fully. ${ }^{58}$ In the restoration of the marred image, von Balthasar harkens back to Irenaeus' theology of recapitulation. Mankind was made in God's image and designed to receive and display God's love; however, due to sin man-

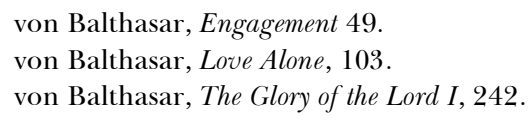

PERICHORESIS 10.2 (2012) 
kind fell and the image was marred. Through the display of God's beauty, von Balthasar sees this image being recapitulated, or restored, to what it once was. The restoration of the image is not merely a post-cross phenolmenon, but a divine glory phenomenon. In Ancient Israel the nation would sing for joy when it saw itself as the fulfilled image of God ${ }^{59}$ It would see itself this way anytime that it properly reflected the glory of the Lord. Though we can never love as deep as the infinite God, being made in His image, we are created to love to the greatest depth that we can.

Given that mankind has an inherent need to share beauty, and that mankind is made in the image of God, it follows that as the beholder's life reflects God's love to a greater degree, he will have an increasingly difficult time closing his eyes to the need for salvation of those around him. ${ }^{60}$ The transformed life will entail that the beholder will desire that everyone sees and images God's beauty in the same manner that he does. This desire is what leads von Balthasar to conclude that the goodness and beauty embedded in Christ draws people out of their seats in the crowd and invites them to join the actors on stage. ${ }^{61}$ There is no place for a passive follower of Christ in this theology. Beauty sparks movement. The one who is docile is the one who has not seen the beauty of the Lord. We presently live in a world full of evil and sin, both of which make life appear meaningless. ${ }^{62}$ However, in the cross of Christ we see either a hidden beauty or an empty meaningless void. The docile beholder either has not actually beheld the hidden beauty or has turned his gaze from that beauty and is therefore complacent in the void. True contact with God's beauty leads to a changed life, which is not satisfied being docile when there are others who need to see that same beauty.

\section{The Transformed Beholder}

Perhaps like none other, Hans Urs von Balthasar makes beauty a central concept in his theological structure. For von Balthasar, beauty is not subjective, it is not in the eye of the beholder and it is not shallow. No, in his thought, beauty is grounded in the being of God and is the revelation of the love of God. Since beauty is inherent to God's absolute being, beauty is objective and carries with it the metaphysical power of the sublime. Anyone

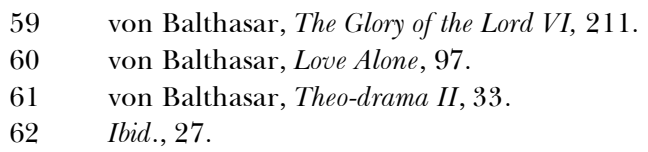


who does not perceive beauty cannot claim that beauty is subjective. In fact, in their inability to perceive beauty they have not shown beauty to be subjective, they have merely revealed that they themselves are ignorant of beauty and therefore, ignorant of God's self-revelation.

God's self-revelation is a revealing of His very nature, which is infused with love. Love and beauty are therefore irrevocably intertwined, and the perception of God's beauty is an experience of God's love. Beauty, by nature, is transcendent and lifts the beholder out of his or her daily life and invites contemplation of the mystery of being. As God's divine beauty is perceived, the beholder is drawn deeper into this beauty, being purified and standing in awe of his creator. This purification and awe begins a transformation in which God's love is infused in the beholder and he or she then begins to once again image God correctly. This process is not a violent one, but one in which the beholder joyously embraces God's beauty, and therefore His love.

The beholder, now enraptured in the divine beauty, seeks to image the divine beauty. As St. John of the Cross taught, God's love now shines from heaven, through the convert. The beholder is now imaging Christ's life due to the transformation that comes from embracing God's beauty. This transformation, called sanctification, entails the development of Christ's ethics, a love for truth, the ability to truly love, a desire to point others to beauty, an awareness of meaning and purpose and a spirit of action as opposed to a docile nature. None of these attributes exist naturally in fallen human nature; they must be infused into that nature by the perception and contemplation of the divine beauty. God's radiant beauty is what reveals His love to a fallen world, and it's what calls that world to repentance and to the life that we were created for. As beings made in His image, it is our privilege and joy to reflect His glory into the world. As von Balthasar explains, "[The church] is the moon, not the sun: the reflection, not the glory itself'" ${ }^{63}$ God's beauty is the impetus for the beholder to live a life that reflects God's glory in all things.

\section{The Need for a Modern Cathedral}

In light of the foregoing, Sartwell's reaction to the Venetian cathedral is not surprising. The building was built with the intent of communicating God's glory. As von Balthasar has accurately pointed out, God's glory and God's 
beauty are one in the same. Further, God glory/beauty and God's love are irrevocably connected. The cathedral in which Sartwell found himself was an architect's attempt to replicate God's glory/beauty in building form. It then follows that the building was also a means whereby he attempted to replicate God's love as well. Von Balthasar's understanding of beauty provides the best explanation for Sartwell's experience: Sartwell found himself touched and almost yearning for there to be a God because he was in a building which properly reflected the glory/beauty and therefore love of God. For a brief moment, in aesthetic form, Sartwell experienced John's declaration in his first epistle "We love God because He first loved us;" however, Sartwell chose to dismiss beauty as opposed to embrace it.

Today, the church does not build cathedrals. In the Evangelical world (in which I find myself), we have never built cathedrals. Churches are pragmatic structures used to house as many bodies as possible. That utilitarian mindset too often finds its way into our preaching and our music as well. The church has shifted its focus to utilitarian concerns about how people live out a faith that they aren't necessarily a part of, or drawn to. After High School, students leave the church in droves, Evangelical and Catholic alike. Why is this the case? It's the case, because the church has not made itself credible. Von Balthasar correctly saw that love alone is credible. This idea is one that priests, pastors, bishops, deacons, cardinals, Bible study leaders and Popes alike must remember and once again take seriously if we are to change our churches. Love is credible because love is attractive. Love is beautiful. Von Balthasar has given us the key to making the church beautiful once again — the key to making ourselves a living cathedral-the church must become loving once more, and in so doing, image Christ's beauty perfectly.

\section{Bibliography}

Gibson, Michael "The Beauty of the Redemption of the World: The Theological Aesthetics of Maximus the Confessor and Jonathan Edwards". The Harvard Theological Review 101.1 (2008).

Crokett, Clayton. Theology of the Sublime. London: Routledge, 2001.

Dubay, Thomas. The Evidential Power of Beauty. Science and Theology Meet. San Francisco, CA: Ignatius Press, 1999.

Hanby, Michael. "Triunity, Creation, and Aesthetic Rationality". American Theological Inquiry 1.2 (2008): 38-62. 
Hart, David Bentley. The Beauty of Infinite. The Aesthetics of Christian Truth. Grand Rapids, MI: Eerdmans, 2003.

Hofer, Andrew. "Proclamation in the Theological Aesthetics of Hans Urs von Balthasar" Worship 79.1 (2005): 20-38.

Kettler, Christian D. "The vicarious beauty of Christ: the aesthetics of the atonement". Theology Today 64.1 (2007): 14-24.

Murphey, Francesca, ed. "Hans Urs von Balthasar: A Gateway to Love". Theological Aesthetics After von Balthasar. Edited by Oleg Bychkov and James Fodor. Hampshire: Ashgate, 2008.

O'Donohue, John. Beauty. The Invisible Embrace. New York, NY: Harper Perennial, 2004.

Sartwell, Crispin. Six Names of Beauty. New York, NY: Routledge, 2006.

Scarry, Elaine. On Beauty and Being Just. Princeton, NJ: Princeton University Press, 1999.

Scruton, Roger. Beauty. Oxford: Oxford University Press, 2009.

von Balthasar, Hans Urs. Engagement with God. Translated by R. John Halliburton. San Francisco, CA: Ignatius, 1975.

. The Glory of the Lord. A Theological Aesthetics, I. Seeing the Form. Edited by Joseph Fessio and John Riches. Translated by Erasmo Leiva-Merikakis. San Francisco, CA: Ignatius, 1982.

. The Glory of the Lord. A Theological Aesthetics; II. Studies in Theological Style. Clerical Styles. Edited by John Riches. Translated by Andrew Louth, Francis McDonagh and Brian McNeil. San Francisco, CA: Ignatius, 1984.

. The Glory of the Lord. A Theological Aesthetics, III. Studies in Theological Style. Lay Styles. Edited by John Riches and Joseph Fessio. Translated by Andrew Louth, John Saward, Martin Simon and Rowan Williams. San Francisco, CA: Ignatius, 1986.

. The Glory of the Lord. A Theological Aesthetics, IV. The Realm of Metaphysics in Antiquity. Edited by John Riches. Translated by Oliver Davies et al. San Francisco, CA: Ignatius, 1989.

. The Glory of the Lord. A Theological Aesthetics; V. The Realm of Metaphysics in the Modern Age. Edited by Brian McNeil and John Riches. Translated by Oliver Davies, Andrew Louth, John Sayward and Martin Simon. San Francisco, CA: Ignatius, 1991.

. The Glory of the Lord. A Theological Aesthetics, VI. Theology. The Old Covenant. Translated by Brian McNeil and Erasmo Leiva-Merikakis. San Francisco, CA: Ignatius, 1991. 
. The Glory of the Lord. A Theological Aesthetics; VII. Theology. The New Covenant. Translated by Brian McNeil. San Francisco, CA: Ignatius, 1989.

Love Alone Is Credible. Translated by D. C. Schindler. San Francisco, CA: Ignatius, 2004.

Theo-drama. Theological Dramatics, II. Dramatis Personae. Man in God. Translated by Graham Harrison. San Francisco, CA: Ignatius, 1976.

Theo-drama. Theological Dramatics, III. Dramatis Personae. Persons in Christ. Translated by Graham Harrison. San Francisco, CA: Ignatius, 1992.

Theo-drama. Theological Dramatics, IV. The Action. Translated by Graham Harrison. San Francisco, CA: Ignatius, 1994.

Viladesau, Richard. "Theosis and beauty". Theology Today 65.2 (2008): 180190. 